\title{
125. On Plectoceras ohtakai Endo from Manchoukuo and Eurystomites chidleyense Foerste from Canada.
}

\author{
By Saburô Shimizu and Tadahiro OBata. \\ Department of Geology, Shanghai Science Institute, Shanghai. \\ (Comm. by H. YABE, M.I.A., Nov. 12, 1935.)
}

Coiled nautiloids are very rare in the Ordovician of Manchoukuo, where straight and curved nautiloids are abundant in the same formation. A single species of coiled nautiloids described by Mr. R. Endo under the name of Plectoceras ohtakai ${ }^{1)}$ Endo is from the Wuting formation, near Pen-hsi-hu colliery. It seems to us to be a member of Trocholitidae, and not referable to Plectoceras which belongs to Plectoceratidae.

Endo's example, unfortunately, is not definitely determinable as it is a poorly preserved external mould, but it is of considerable interest and worthy of discussion as an indication of the probable occurrence of Discoceras in the Manchoukuo Ordovician. The characteristics of the specimen according to Endo's figure and description are its gradually enlarging whorls, prominent ribs, and subangular umbilical margin.

Endo seems to have understood Plectoceras as having subangular umbilical margin and ribs prominent even to the umbilical margin; as a matter of fact, however, proper to the genus are broadly rounded umbilical margin and somewhat weak ribs, which are most prominent on the ventrolateral margin and generally become obsolete towards the umbilical margin. These remarks are sufficient at least to discriminate the Manchoukuo example from Plectoceras.

The form in question shows some resemblance to certain genera of Tarphyceratidae, and especially to Eurystomites. The genotype of Eurystomites Whiteaves, Nautilus kelloggi $i^{2}$ is characterised by: 1 . rather rapidly enlarging compressed whorls; 2 . oblong-elliptical whorlshape; 3 . broadly rounded umbilical and ventral margin; 4 . slightly flexuous suture-line; 5 . small subventral siphuncle; 6 . weak ribs which are obsolete towards the umbilical margin.

The Manchoukuo example is distinguished from the typical Eurystomites by possessing not only less rapidly enlarging and less impressed whorls and more prominent costation, but also a more angular umbilical margin. Some of the forms included by Foerste in Eurystomites, e.g. $E$. chidleyense ${ }^{3)}$ Foerste indicate the existence of yet another different group of Eurystomitids that requires a separate generic designation and the new generic name Chidleyenoceras gen. nov. is here proposed for it, taking as the genotype Eurystomites chidleyense (Pl. XX; pl. XXVII, Fig. 2 A-F) figured by Foerste. The most noteworthy points

1) Endo, E.: The Canadian and Ordovician Formations and Fossils of South Manchuria, U. S. National Museum, Bull. 164, 1932, p. 73, pl. XXIV.

2) Foerste, A. F.: American Arctic and Related Cephalopods, Denison Univ. Bull., Journ. Sci. Lab., Vol. XXIII, 1928, p. 56, pl. XVI, fig. 2 ; pl. XXVII, fig. 1.

3) Foerste: ibid., p. 58, pl. II, fig. 2 A-C; pl. XX, fig. 1 ; pl. XXVII, fig. 2 A-F. 
of the demarcation of the genus from Eurystomites are 1. depressed, divergent whorls, which are quadrangular or rather somewhat trapezoidal in cross-section; 2 . large subventral sipuncle ; 3 . strongly flexuous sutureline. Of these the first one is the most attractive.

The Manchoukuo example is undoubtedly closer to Chidleyenoceras than to Eurystomites, but it differs from Chidleyenoceras in having more prominent costation.

On the other hand the form under consideration seems to be closest to Discoceras antiquissimum ${ }^{1}$ (Eichwald), which is the genotype of the genus. This is characterised by the following features: 1. gradually enlarging whorls, with quadrangular whorl-shape; 2 . well-defined subangular umbilical margin; 3. prominent costation; 4. subdorsal siphuncle; 5. strongly flexuous suture-line.

The Manchoukuo example, however, differs from Discoceras antiquissimum in its more crowded costation.

In the absence of siphuncle and suture-line, definite identification of the specimen is impossible, but we shall place provisionally the Manchoukuo example in Discoceras, until better specimen are obtained.

1) Foerste: Note on Cephalopod Genera chiefly Coiled Silurian Forms, ibid., XXI, 1925, p. 58, pl. XVIII, figs. 1 A, 1 B; Barrande, J.: Systême Silurien du Centre de la Bohême, Vol. II, Supplement, 1877, pl. CCCCLXXV, fig. 13. 